\title{
Synthesis, Characterization, Chelating Properties and Anti-Fungal Activity of 2-(4-Phenylpiperazinyl) Methyl-3- (8-Quinolinol-5-Yl)- 4(3h)-Quinazolinone
}

\author{
C. D. SHELAT AND R. T. VASHI \\ Department of Chemistry, \\ Navyug Science College, Surat-395 000, Gujarat State, INDIA.
}

Received 19 November 2004; Accepted 14 December 2004

\begin{abstract}
A new quinazolinone derivative namely 2-(4-phenylpiperazinyl)methyl-3(8-quinolinol-5-yl)- 4(3h)-quinazolinone(HL) was prepared and characterized. Various transition metal $\left(\mathrm{Cu}^{2+}, \mathrm{Co}^{2+}, \mathrm{Ni}^{2+}, \mathrm{Zn}^{2+}, \mathrm{Mn}^{2+}\right)$ chelates of $\mathrm{HL}$ were prepared and characterized by metal ligand (M:L) ratio, IR and reflectance spectral studies, magnetic moment, and antimicrobial activity.
\end{abstract}

Key words: Synthesis, Characterization, Chelating properties and anti-fungal activity.

\section{Introduction}

Report shows that various scientists investigated the quinazolone derivatives as biological and pharmaceutical agents ${ }^{1-6}$. Most of quinazolone containing phenyl group at 3 position. The area in which the quinazolones containing metal chelating moiety(i.e. ligand) say 8-hydroxy quinoline has not been developed inspite of the 8-hydroxy quinoline is well known metal precipitant. Hence it was aimed to explore the field of quinazolone-8-hydroxy quinoline combined molecules. The present paper comprises the synthesis, characterization, chelating properties and microbial activity of the quinazolone compound having following synthetic route. 


\section{Scheme-I}
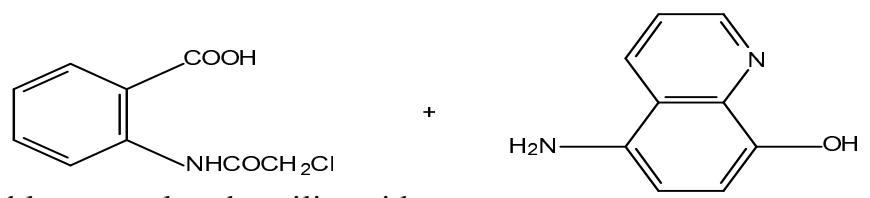

$\mathrm{N}$-chloroacetyl anthranilic acid

5-Amino-8-quinolinol

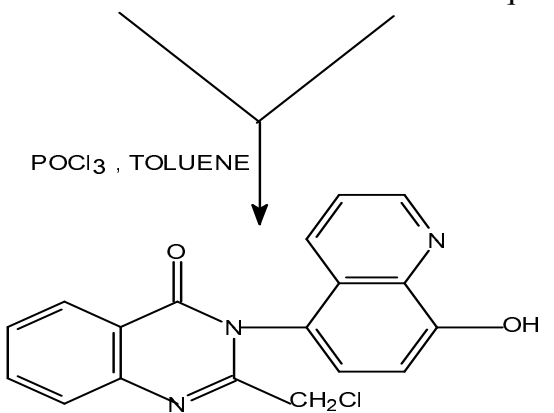

2-chloromethyl-3-(8-quinolinol-5-yl)-4-3(H)(quinazolinone)

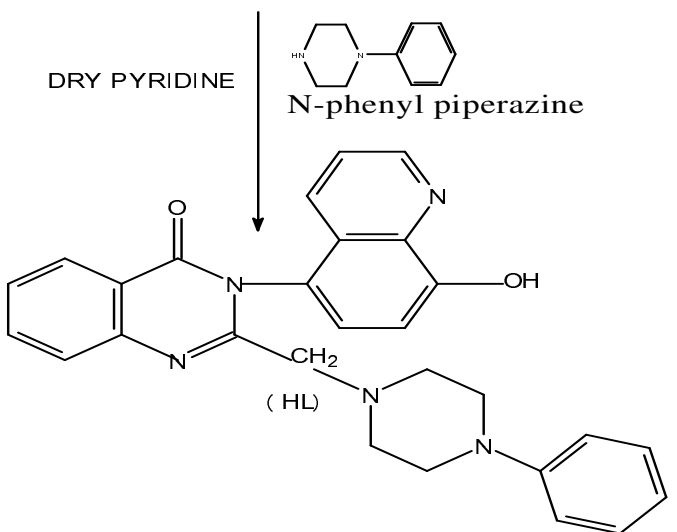

2-(4-phenyl piperazinyl)methyl-3-(8-quinolinol-5-yl)-4-(3H) quinazolinone (HL)

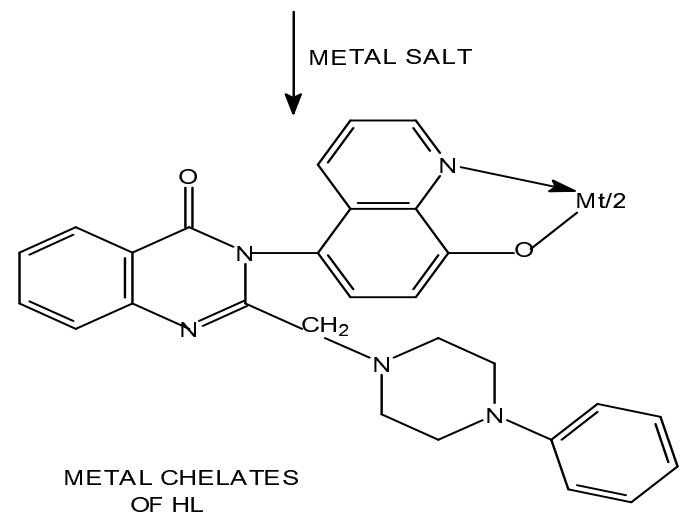

Where $\mathrm{Mt}: \mathrm{Cu}^{2+}, \mathrm{Co}^{2+}, \mathrm{Ni}^{2+}, \mathrm{Zn}^{2+}, \mathrm{Mn}^{2+}$ 


\section{Experimental}

Materials

5-Amino-8-quinolinol was prepared accordingly to literature method ${ }^{7}$. N-phenyl piperazine was obtained from Enzal Chemicals, Ankleshwar. All other chemicals were used of pure grade.

\section{Synthesis}

2-chloromethyl-3-(8-quinolinol-5-yl)-4-3(H)(quinazolinone):

A mixture of $\mathrm{N}$-chloroacetyl anthranilic acid( 0.1 mole $)$ and 5-amino-8-quinolinol $(0.1 \mathrm{~mole})$ and $\mathrm{PCl}_{3}$ ( 0.1 mole) in dry toluene was refluxed under anhydrous condition for 9 hours. The reaction was kept up to cooling and $\mathrm{PCl}_{3}$ was decomposed by cold water. Then toluene was distilled off to get the product. It was filtered, washed with $\mathrm{NaHCO}_{3}(10 \%$ solution) and then cold water. It was yellowbrown amourphous powder. Melting point $217^{\circ}-218^{\circ} \mathrm{C}$ (uncorrected). $\mathrm{N} \%$ Calculated 12.44 . Found 12.35. Calculated 10.52 Found 10.4

Synthesis of 2-(4-phenyl piperazinyl)methyl-3-8-quinolinol-5-yl-4-(3H) quinazolinone $(H L)$ : A mixture of 2-chloromethyl-3-(8-quinolinol-5-yl)-4(3H) quinazolinone $(0.05$ mole) and N-phenyl piperazine $(0.05$ mole) in dry pyridine was refluxed for 10 hours. Pyridine was distilled off as much as possible and the residue was poured in to a little crushed ice. It was filtered, washed with water and air-dried. The yield was $80 \%$. Melting Point $=230^{\circ}-231^{\circ}$ (uncorrected).

Preparation of metal chelates of $H L$ :

The $\mathrm{Cu}^{2+}, \mathrm{Co}^{2+}, \mathrm{Ni}^{2+}, \mathrm{Zn}^{2+}$ and $\mathrm{Mn}^{2+}$ metal chelates of HL ligand were prepared in the similar manner. The general procedure is as follows:

The HL $(0.02$ mole) was suspended in formic acid $(10 \mathrm{ml})$. Then water is added till the HL dissolved completely. Then the solution is added in to the metal acetate $(0.01$ mole) solution in water $(100 \mathrm{ml})$. The resultant mixture was added by sodium acetate. The precipitates of chelates were settle down and digested on hot water bath for 2 hours. The precipitate of metal chelates were filtered off, washed and air-dried. It was amourphous, dark coloured powder. Yield was quantitave. It did not melt or decomposed up to $230^{\circ} \mathrm{C}$. The details of all chelates are presented in Table-1.

\section{Measurement :}

The elemental analysis for $\mathrm{C}, \mathrm{H}$, and $\mathrm{N}$ were carried out on Carlo Erba elemental analyzer(Italy). IR spectra of HL and the coordination metal chelates were scanned on a Perkin Elmer FTIR Spectrophotometer in $\mathrm{KBr}$. The metal content of the metal chelates were performed by decomposing a weighed amount of each coordination metal chelates followed by EDTA titration as reported in literature ${ }^{8}$. Magnetic succeptibily measurements of all the coordination metal chelates were carried out at room temperature by the Gouy method. Mercury tetrathiocynatocobaltate(II). $\mathrm{Hg}\left[\mathrm{Co}(\mathrm{NCS})_{4}\right]$ was used as a calibrant. The diffused reflectance spectra of solid coordination metal chelates were recorded on a Backman DK-2A Spectrophotometer with a solid reflectance attachments. $\mathrm{MgO}$ was employed as the reflectance compound.

\section{Anti-fungal activity :}

The fungicidal activity of all the compounds were studied at $1000 \mathrm{ppm}$ concentration in Vitro. Plant pathogenic organisms used were. Penicillium Expansum, Botrydepladia Thiobromine, Nigrospora Sp. The antifungal activity of all the samples were measured on each of these plant pathogenic strains on a potato dextrose agar(PDA) medium. Such a PDA medium contained ${ }^{9}$ potato $200 \mathrm{gms}$, dextrose 20 gms, agar $20 \mathrm{gms}$ and water 1 litre. 5 days old culter were employed. The compounds to be tested were suspended $(1000 \mathrm{ppm})$ in a PDA medium and autoclaved at $120^{\circ} \mathrm{C}$ for $15 \mathrm{~min}$. at $15 \mathrm{~atm}$ pressure. These medium were poured into sterile petri plate and the organisms were inoculated after cooling the Petri plates. The percentage inhibition for fungi was calculated after 5 days using the formula given below.

$$
\text { Percentage of Inhibition }=\frac{100(\mathrm{X}-\mathrm{Y})}{\mathrm{X}}
$$

Where, $\mathrm{X}$ : Area of colony in control plate, $\mathrm{Y}$ : Area of colony in test plate The fungicidal activity displayed various compound as shown in Table-2. 


\section{Results and Discussion}

The ligand was synthesized as shown in the Scheme-1.HL is a amorphous yellow powder, soluble only in DMSO and DMF. The results of elemental analysis of the ligand reported in Table-1 are consistant with the predicted structure as shown in Scheme-1. Examination of IR spectrum (not shown) of HL reveals that a broad band of phenolic hydroxyl stretching is observed at $3300-3500 \mathrm{~cm}^{-1}$ as well as additional absorption band at 1427, 1481, 1508 and $1602 \mathrm{~cm}^{-1}$ characteristics of the 8-hydroxy quinoline moiety ${ }^{10}$. The weak bandsat -2920 and $2850 \mathrm{~cm}^{-1}$ are arised from $\mathrm{CH}_{2}$ piperazine ring and $\mathrm{CH}_{2}$ group. The bands due to aromatic ring are observed at their respectable positions. The strong band at 1690 and 1630 are attribute respectively to $\mathrm{C}=\mathrm{O}$ and $\mathrm{C}=\mathrm{N}$ bands ${ }^{11}$.

The metal chelates of $\mathrm{HL}$ with the metal ions $\mathrm{Cu}^{2+}, \mathrm{Co}^{2+}, \mathrm{Ni}^{2+}, \mathrm{Zn}^{2+}, \mathrm{Mn}^{2+}$ vary in dark colours. On the basis of the proposed structure as shown in scheme-I, the molecular formula of the HL ligand is $\mathrm{C}_{28} \mathrm{H}_{25} \mathrm{~N}_{5} \mathrm{O}_{2}$. Which upon chelation coordinates with one central metal atom at four coordination sites and with tow water molecules. Therefore, the general molecular formula of the resulting metal chelat is given by $\left[\mathrm{C}_{28} \mathrm{H}_{24} \mathrm{~N}_{5} \mathrm{O}_{3}\right]_{2} \mathrm{M} .2 \mathrm{H}_{2} \mathrm{O}$. This has been confirmed by results of elemental analysis of all the five metal chelates and their parent ligand. The data of elemental analysis reported in Table-1 are in arrangement with the calculated values of $\mathrm{C}, \mathrm{H}$, and $\mathrm{N}$ based on the above mentioned molecular formula of parent ligand as well as coordination metal chelates.

Inspection of the IR Spectra(not shown) of metal chelates reveals that all the spectra are identical in all respects. The comparison of IR spectrum of the parent ligand HL with that of its each metal chelates has revealed certain characteristics differences.One of the significant difference to be expected between the IR spectrum of the parent ligand and its metal coordinated chelates is the presence of more broadened bands in the region of $3300-3550 \mathrm{~cm}^{-1}$ for the coordination metal chelates as the oxygen of the $\mathrm{O}-\mathrm{H}$ group of the ligand forms a coordination bond with the metal ions. This is explained by the fact that water molecules might have strongly absorbed to the metal chelates sample during their formation. Another noticeable difference is that the band due to the $\mathrm{C}=\mathrm{N}$ stretching vibration of 8hydroxy quinoline at $1600 \mathrm{~cm}^{-1}$ in the IR spectrum of $\mathrm{HL}$ is shifted to lower frequency. The band at $1400 \mathrm{~cm}^{-1}$ in the IR spectrum of HL assigned to in-plane $\mathrm{OH}$ deformation ${ }^{10}$ is shifted towards higher frequency of the spectra of the metal chelates due to the formation of metal -oxygen bands. This has been further confirmed by a weak band at $1105 \mathrm{~cm}^{-1}$ corresponding to C-O-M stretching ${ }^{10}$. Thus all of these characteristics/features of the IR studies suggested the structure of the metal chelates as shown in Figure.

Examination of data of the metal content in each compound revealed a 1:2 metal : ligand $\left(\mathrm{ML}_{2}\right)$ stoichiometry in all of the chelates.Magnetic moment $\left(\mu_{\text {eff }}\right)$ of each of the metal chelate is given in Table-1. Examination of these data reveals that all coordination chelates other than, that of $\mathrm{Zn}$ (II) are para-magnetic while that of $\mathrm{Zn}$ (II) is diamagnetic.The diffuse electronic spectrum of the $\left[\mathrm{CuL}\left(\mathrm{H}_{2} \mathrm{O}\right)_{2}\right]$ metal chelates shows broad bands at 15878 and $22998 \mathrm{~cm}^{-1}$ due to the ${ }^{2} \mathrm{~T}_{\mathrm{g}} \rightarrow^{2} \mathrm{~T}_{2 \mathrm{~g}}$ transition and charge transfer, respectively, suggesting a distorted octahedral structure for the $\left[\mathrm{CuL}\left(\mathrm{H}_{2} \mathrm{O}\right)_{2}\right]$ chelates which is further confirmed by the higher value of $\mu_{\text {eff }}$ of the $\left[\mathrm{CuL}\left(\mathrm{H}_{2} \mathrm{O}\right)_{2}\right]$ chelat. The $\left[\mathrm{NiL}\left(\mathrm{H}_{2} \mathrm{O}\right)_{2}\right]$ and $\left[\mathrm{CoL}\left(\mathrm{H}_{2} \mathrm{O}\right)_{2}\right]$ chelates gave two absorption bands respectively, at 15623,22473 and $16524,22220 \mathrm{~cm}^{-1}$ corresponding to ${ }^{4} \mathrm{~T}_{1 \mathrm{~g}} \rightarrow{ }^{2} \mathrm{~T}_{1 \mathrm{~g}}$ and ${ }^{4} \mathrm{~T}_{1 \mathrm{~g}} \rightarrow{ }^{4} \mathrm{~T}_{1 \mathrm{~g}}(\mathrm{P})$ transitions. Thus, absorption bands of the diffuse, reflectance spectra and the values of the magnetic moments $\left(\mu_{\text {eff }}\right)$ indicate an octahedral configuration for the $\left[\mathrm{NiL}\left(\mathrm{H}_{2} \mathrm{O}\right)_{2}\right]$ and $\left[\mathrm{CoL}\left(\mathrm{H}_{2} \mathrm{O}\right)_{2}\right]$ chelates. The spectra of $\left[\mathrm{MnL}\left(\mathrm{H}_{2} \mathrm{O}\right)_{2}\right]$ shows weak bands at 14666,19752 and $25571 \mathrm{~cm}^{-1}$ assigned to the transitions ${ }^{6} \mathrm{~A}_{1 \mathrm{~g}} \rightarrow{ }^{4} \mathrm{~T}_{1 \mathrm{~g}}(4 \mathrm{G}),{ }^{6} \mathrm{~A}_{1 \mathrm{~g}} \rightarrow{ }^{4} \mathrm{~T}_{2 \mathrm{~g}}(4 \mathrm{G})$ and ${ }^{6} \mathrm{~A}_{1 \mathrm{~g}}$ (F) $\rightarrow{ }^{4} \mathrm{~T}_{1 \mathrm{~g}}$, respectively suggesting an octahedral structure for the $\left[\mathrm{MnL}\left(\mathrm{H}_{2} \mathrm{O}\right)_{2}\right]$ chelate. As the spectrum of the $\left[\mathrm{ZnL}\left(\mathrm{H}_{2} \mathrm{O}\right)_{2}\right]$ polymer is not well resolved, it is not interpreted but its $\mu_{\text {eff }}$ value, shows that it is diamagnetic as expected.

The antifungal activity of all the compounds measured for various plant pathogens. Inspection of the result shown in Table-2 indicates that all compounds are good toxic for fungi. Out of all the compounds Copper chelate is more toxic than others. These compounds almost inhibit the fungi about 
70\%. Hence, produced metal chelates can be employed as garden fungicides. Further work in this direction is in progress.

Table-1 Analytical Data of the coordination metal chelats of HL

\begin{tabular}{|c|c|c|c|c|c|c|c|c|}
\hline \multirow[t]{2}{*}{ Compound } & \multirow{2}{*}{$\begin{array}{l}\text { Empirical } \\
\text { Formula }\end{array}$} & \multirow{2}{*}{$\begin{array}{l}\text { Formula } \\
\text { Weight } \\
\text { Gm/mole }\end{array}$} & \multirow{2}{*}{$\begin{array}{c}\text { Yiel } \\
\text { d } \\
(\%)\end{array}$} & \multicolumn{4}{|c|}{$\begin{array}{l}\text { Elemental Analysis \% } \\
\text { Found/(Calcd.) }\end{array}$} & \multirow[t]{2}{*}{$\begin{array}{l}\mu_{\text {eff }} \\
\mathrm{BM}\end{array}$} \\
\hline & & & & $\mathrm{C}$ & $\mathrm{H}$ & $\mathrm{N}$ & $\mathrm{M}$ & \\
\hline HL & $\mathrm{C}_{28} \mathrm{H}_{25} \mathrm{~N}_{5} \mathrm{O}_{2}$ & 463 & 72 & $\begin{array}{c}72.48 \\
(72.57)\end{array}$ & $\begin{array}{c}5.37 \\
(5.39)\end{array}$ & $\begin{array}{c}15.07 \\
(15.11)\end{array}$ & - & - \\
\hline$\left[\mathrm{CuL}_{2}\left(\mathrm{H}_{2} \mathrm{O}\right)_{2}\right]$ & $\begin{array}{c}{\left[\mathrm{C}_{28} \mathrm{H}_{24} \mathrm{~N}_{5} \mathrm{O}_{3}\right]_{2} \mathrm{Cu}} \\
.\end{array}$ & 1019.54 & 83 & $\begin{array}{c}32.89 \\
(32.95)\end{array}$ & $\begin{array}{c}2.33 \\
(2.35)\end{array}$ & $\begin{array}{c}6.81 \\
(6.86)\end{array}$ & $\begin{array}{c}6.22 \\
(6.23)\end{array}$ & 1.98 \\
\hline$\left[\mathrm{CoL}_{2}\left(\mathrm{H}_{2} \mathrm{O}\right)_{2}\right]$ & $\begin{array}{c}{\left[\mathrm{C}_{28} \mathrm{H}_{25} \mathrm{~N}_{5} \mathrm{O}_{2}\right]_{2} \mathrm{Co}} \\
.\end{array}$ & 1014.93 & 89 & $\begin{array}{c}33.06 \\
(33.10)\end{array}$ & $\begin{array}{c}2.32 \\
(2.35)\end{array}$ & $\begin{array}{c}6.87 \\
(6.89)\end{array}$ & $\begin{array}{c}5.77 \\
(5.80)\end{array}$ & 4.65 \\
\hline$\left[\mathrm{NiL}_{2}\left(\mathrm{H}_{2} \mathrm{O}\right)_{2}\right]$ & 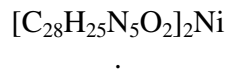 & 1014.69 & 79 & $\begin{array}{c}33.03 \\
(33.11)\end{array}$ & $\begin{array}{c}2.30 \\
(2.36)\end{array}$ & $\begin{array}{c}6.86 \\
(6.89)\end{array}$ & $\begin{array}{c}5.74 \\
(5.78)\end{array}$ & 3.11 \\
\hline $\begin{array}{l}{\left[\mathrm{MnL}_{2}\right.} \\
\left.\left(\mathrm{H}_{2} \mathrm{O}\right)_{2}\right]\end{array}$ & $\begin{array}{c}{\left[\mathrm{C}_{28} \mathrm{H}_{25} \mathrm{~N}_{5} \mathrm{O}_{2}\right]_{2} \mathrm{M}} \\
\mathrm{n} .\end{array}$ & 1010.93 & 86 & $\begin{array}{c}33.22 \\
(33.23)\end{array}$ & $\begin{array}{c}2.31 \\
(2.37)\end{array}$ & $\begin{array}{c}6.88 \\
(6.92)\end{array}$ & $\begin{array}{c}5.41 \\
(5.43)\end{array}$ & 5.11 \\
\hline$\left[\mathrm{ZnL}\left(\mathrm{H}_{2} \mathrm{O}\right)_{2}\right]$ & $\begin{array}{c}{\left[\mathrm{C}_{28} \mathrm{H}_{25} \mathrm{~N}_{5} \mathrm{O}_{2}\right]_{2} \mathrm{Zn}} \\
.\end{array}$ & 1021.39 & 88 & $\begin{array}{r}32.82 \\
(32.89) \\
\end{array}$ & $\begin{array}{c}2.33 \\
(2.34) \\
\end{array}$ & $\begin{array}{r}6.79 \\
(6.85) \\
\end{array}$ & $\begin{array}{r}6.34 \\
(6.40) \\
\end{array}$ & $\mathrm{D}$ \\
\hline
\end{tabular}

$\underline{\text { Table-2 : Antifungal activity of compounds }}$

\begin{tabular}{cccc}
\hline \multicolumn{4}{c}{ Zone of inhibition at $1000 \mathrm{ppm}(\%)$} \\
\hline Compounds & Fungus \\
\hline $\mathrm{HL}$ & 71 & $\begin{array}{c}\text { Botrydepladia } \\
\text { Thiobromine }\end{array}$ & Nigrospora Sp. \\
\hline $\left.\mathrm{CuI}\left(\mathrm{H}_{2} \mathrm{O}\right)_{2}\right]$ & 82 & 65 & 63 \\
{$\left[\mathrm{CoI}\left(\mathrm{H}_{2} \mathrm{O}\right)_{2}\right]$} & 76 & 91 & 96 \\
$\left.\mathrm{NiI}\left(\mathrm{H}_{2} \mathrm{O}\right)_{2}\right]$ & 73 & 69 & 74 \\
{$\left[\mathrm{MnI}\left(\mathrm{H}_{2} \mathrm{O}\right)_{2}\right]$} & 77 & 76 & 68 \\
$\left.\mathrm{ZnI}\left(\mathrm{H}_{2} \mathrm{O}\right)_{2}\right]$ & 68 & 61 & 72 \\
& & 65 & 69 \\
\hline
\end{tabular}

\section{Acknowledgement}

One of authors (CDS) thanks to M/s. Aglowmed Limited, Ankleshwar for providing analysis as well as biological activity. The author (CDS) is also grateful to M/s. Enzal Chemicals, Panoli for providing important chemicals. The author is also thanks to Dr. A. S. Patel, Principle, Navyug Science College for encouragement and providing necessary research facilities.

\section{References}

1. Gujral M L, Kohli R P and Saxena P N , J. Assoc Physicians, 1955, 2, 29.

2. Gujral M L, Kohli R P and Saxena P N, Indian J. Res.,1957, 45, 207

3. Shelly B V, Campanella and Katino J W, "CNS Drugs", CSRI, New Delhi, 1966, 156.

4. Kackar I K, and Zaheer S H, J. Ind. Chem. Soc., 1981, 28, 334

5. Alaino R J and Hatton C Z, J. Med. Chem., 1972, 15, 108.

6. Shukia J S, Singh M and Rastogi R, Indian J. Chem., 1983, 30 B. 228,

7. Dudleg D, Thustom J, Schetarf F, Holm D, Hansen H, Hull C and Adam P, J. Am. Chem. Soc., 1951, 73, 2986,.

8. Vogel A I, Inorganic Quantitative Analysis; $4^{\text {th }}$ Ed., ELBS: London, 1978

9. Harstall J G, Bot. Rev., 1945, 11, 357

10. Charles R G, Freiser H F, Priedel R, Hilliand L E and Johnston R. D, Spectrochem Acta $1958,8,1$.

11. Patel B K and Patel M M, Journal of Indian Council of Chemists, 1988, Vol.IV, 2, , 33 


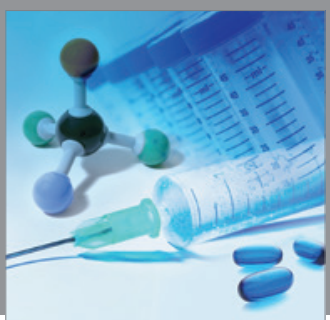

International Journal of

Medicinal Chemistry

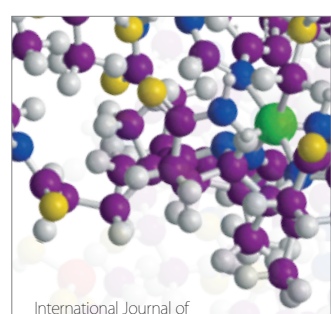

Carbohydrate Chemistry

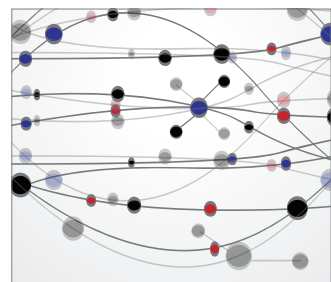

The Scientific World Journal
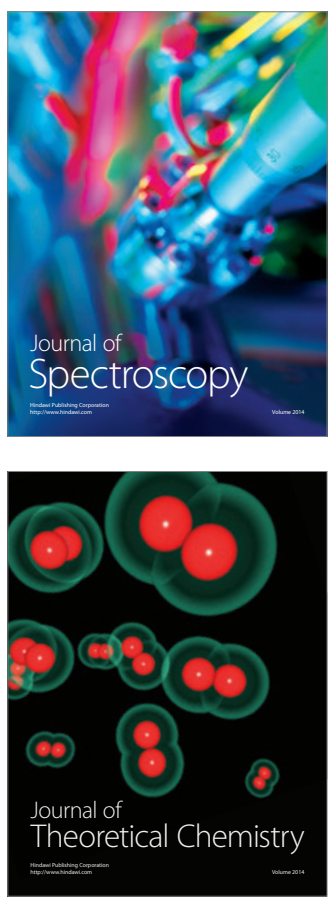
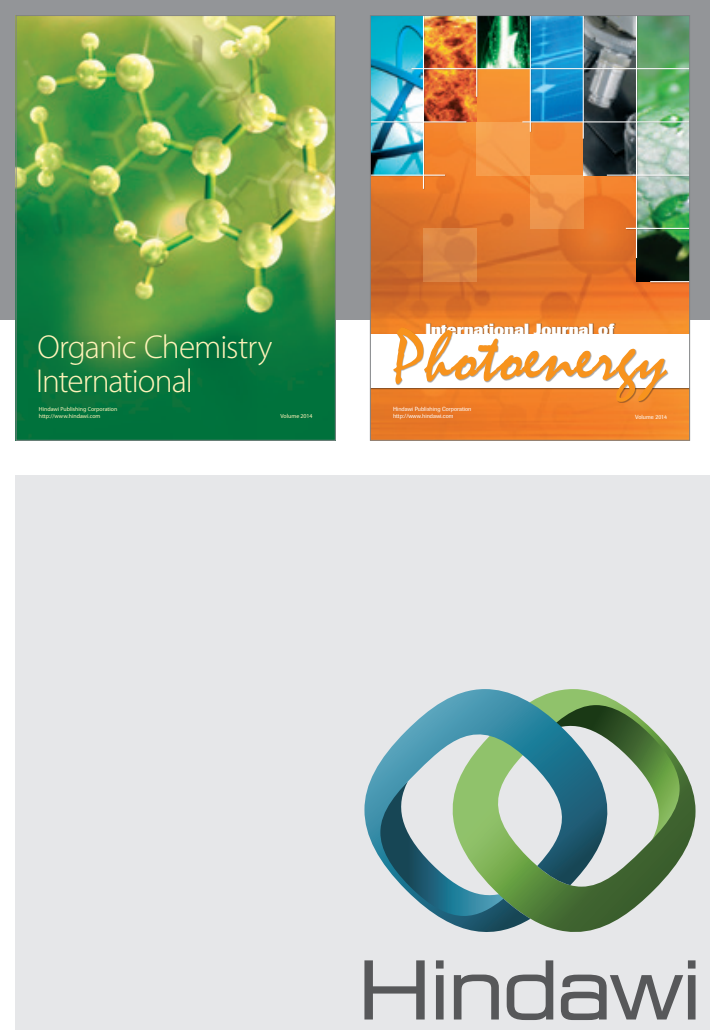

Submit your manuscripts at

http://www.hindawi.com
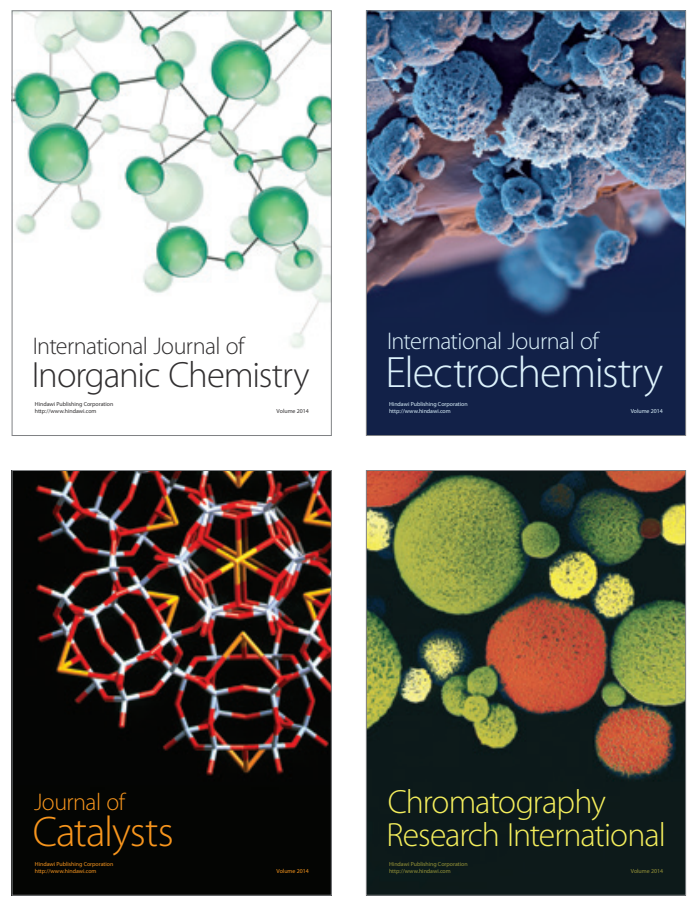
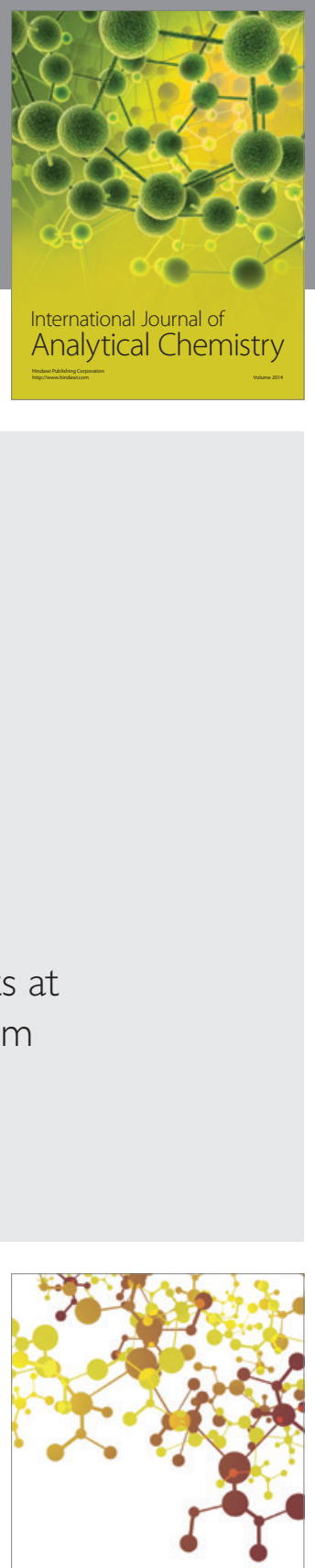

Journal of

Applied Chemistry
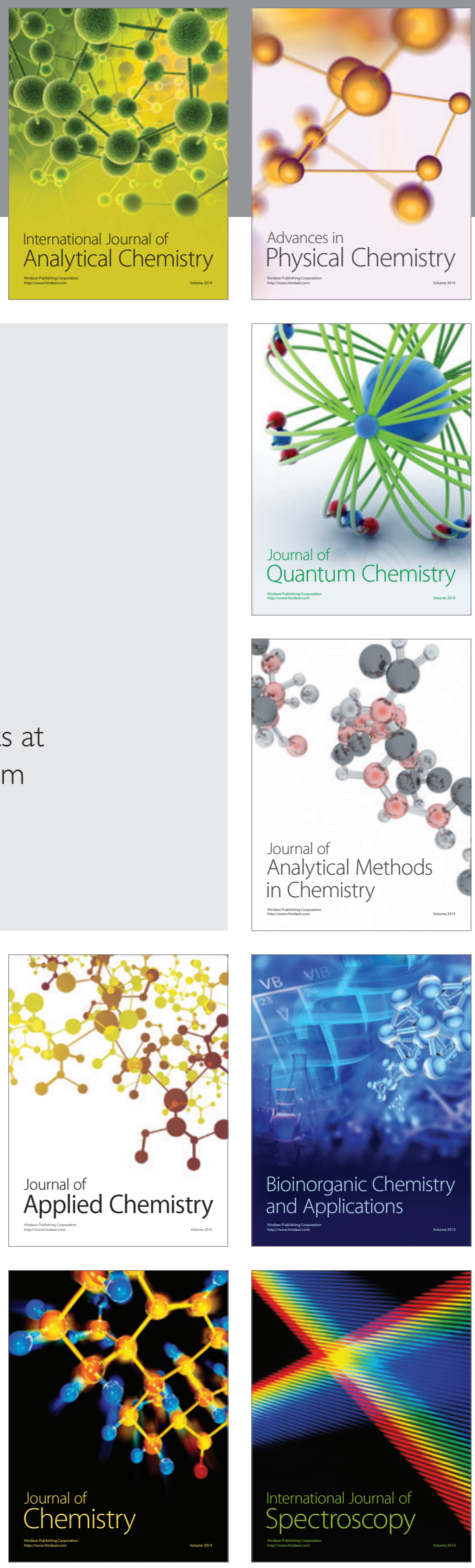